\begin{tabular}{c} 
Volume and Issues Obtainable at Center for Sustainability Research and Consultancy \\
Journal of Accounting and Finance in Emerging Economies \\
ISSN: 2519-0318 ISSN (E) 2518-8488 \\
Volume 5: Issue 2 December 2019 \\
CSRᄃ \\
Journal homepage: www.publishing.globalcsrc.org/jafee \\
\hline
\end{tabular}

\title{
Effect of Trade Credit on Firms Growth: A Case Study of Pakistani Non-financial Firms
}

\author{
${ }^{1}$ Hafiz M. Adnan Hanif \\ ${ }^{1}$ Lecturer, Pakistan Institute of Development Economics, Quaid-i-Azam University Campus، Islamabad, Pakistan, \\ Adnanhanif190b@gmail.com
}

\begin{tabular}{l} 
ARTICLE DETAILS \\
\hline History \\
Revised format: November 2019 \\
Available Online: December 2019
\end{tabular}

Keywords

Trade Credit, Firms' Growth,

Sales Growth, Non-Financial Firms

ABSTRACT

Purpose: Most of the businesses move from traditional business transactions to automated and sophisticated credit transaction methods. As large firms have better access to financial institutions and markets but still, they are interested to seek firm growth by adopting the trade credit policies. Finally, the non-financial listed firms of Pakistan can achieve their growth targets by adopting trade credit policies

Design/Methodology/Approach: This study collects information

JEL Classification:

F13,F19,F43,F49 from non-financial firms of Pakistan. Panel data is used to explore the impact of trade credit on firm's growth. The data collected from the year 2001- 2015 of 257 non-financial firms of Pakistan. A technique of panel data analysis, generalized method of moment used to analyze the data.

Findings: The results suggest that trade credit and GDP have a positive significant impact on firms' growth. Moreover, the Firm's age, its size and inflation in the economy have also impacted the firm's growth but in a negative direction.

Implications/Originality/Value: As trade credit is a source of Firms Growth So, for better growth of firms management must be taken step for better trade credit policies.

(C) 2019 The authors, under a Creative Commons Attribution-Non

Commercial 4.0

Corresponding author's email address: Adnanhanif190b@gmail.com

Recommended citation: Hanif, H. M. A. (2019). Effect of Trade Credit on Firms Growth: A Case Study of Pakistani Non-financial Firms. Journal of Accounting and Finance in Emerging Economies, 5 (2), 167-178

DOI: $10.26710 /$ jafee.v5i2.621

\section{Introduction}

Firms have to clearly monitor financial performances to enhance their growth. Nowadays financing is a big task and considered as lifeblood for firms. There are decisions for capital budgeting which consists of making the best choices among the available resources. Another most important decision is about the management of working capital because it deals with current assets and current liabilities (Raheman \& Nasr, 2007) and hence directly 
affects the liquidity and profitability position of the companies1. So, working capital should be properly managed and monitor to overcome the short-term finances requirement of the companies. One of the major sources of working capital is trade credit. Trade credit is the relationship between buyer and supplier and it has become an integral part of today's business. Trade credit arises whenever a buyer defers payments to the suppliers. In the beginning when goods and services provided by the producer to its customer no payment is made. The price of goods and services is made on an agreed near future date according to the agreement done among the parties. So, it is the most important source of short-term external finance, which companies get directly from their suppliers (Petersen \& Rajan, 1997).

According to (Marotta, 1997) the importance of the use of trade credit varies from country to country. Trade credit is extensively used nowadays in many sorts of businesses, especially financially distressed firms prefer to take the trade credit option. These companies decide to efficiently utilize the capital structure to achieve many business objectives. Mostly trade-credit users are the industrial sectors of the country because they require the investments or goods on a daily basis. According to the survey held in Finland (1996), the receivables are, on average 9.7 percent and payables are 6.1 percent as per balance sheet items. In the United States, trade credit has a major source of capital for many companies. According to the major utilizer of trade credit the world's largest mart, the Wal-Mart has the largest source of transactions in their accounts as of trade credit transactions. It is very easy for these largesized marts to get bank loans, but however, Wal-Mart prefers trade credit over bank borrowings.2 In developed countries like France, Germany and Italy the worth of trade credit assets is almost a quarter of total corporate assets. Trade credit is important for those economies where firms get limited help from banking services and other financial sectors. One example of such economies are China as argued by (Ge \& Qiu, 2007).

Although bank financing is considered as a major source of financing by firms but at the same time financing through trade credit is very important due to many advantages attached to it. Trade credit mostly becomes a source of capital to the Firms that are unable to raise capital through traditional channels. The trade held on credit terms not only generates the expansion of businesses but also builds a long-term relation between buyers and suppliers. Suppliers provide the capital to the buyers to expand their own business. In comparison with the financial institutions, the suppliers are well aware of the market conditions for the products which provide an edge to the suppliers better than banks and other financial institutions. Suppliers use and implement the information of monitoring and controlling for the purpose of repayment in many different ways which are helpful for the buyers. Therefore, the terms and conditions for trade credit differ from buyer to buyer. Suppliers as being fully aware of the markets have abilities to resell the products for generating the credit. Suppliers have full knowledge as well as expertise as compared to the financial institutions held which is necessary for the control of risk faced by the buyers. The transaction cost also reduced because trade credit doesn't require any transaction charges between the two parties, just the contract letter is enough to fulfill the agreement. Trade credit serves as the best mean for the detection of quality of goods because suppliers don't want to lose precious or regular buyers and also to maintain a healthy business relationship is necessary for the future prospects of businesses. According to (Berger \& Udell, 1995) small and medium-sized firms faced many sorts of difficulties in achieving the external source of financing like bank loans. But in case of trade credit as there are no such formalities attached to trade credit as required in bank financing So, small scale firms also get trade credit easily (Storey, 2016). Trade credit is also a major source when credit from financial institutions is not available or there is a shortage of liquid funds then small firms rely more on trade credit (Elliehausen \& Wolken, 1993).

Another benefit is that firms get short term debt easily without involving in lengthy formalities to achieve loans because the formal bank loan issued after a prolonged and complicated procedure. This indicates that one can only receive a bank loan after going through many difficult and time-consuming terms and conditions which itself is not a simple scenario. For this reason, the new market entered firms and small-scaled firms may not be able to get bank credits easily as they did not meet the formal bank requirements (Storey, 2016). According to the survey held in 2005 in Spain, Firms who are suffering from credit constraints rely on trade credit as a source of funding. The

1 The earning capacity of short-term assets is less than the long-term assets. Therefore, when firm put more on current assets then it profits earning decrease. On the other hand, when firm have more current liabilities over current assets then liquidity problem may exist.

2 Wal-Mart uses the trade credit as it is beneficial for the delayed payments and to achieve purchases timely and without loss of time. As per the annual report of Wal-Mart in 2006, a high rate and standardized large buyer has account payables of short-term funding three quarters of its total debt. 
financial institutions also gain the signal that these small and medium-sized firms are well established and can be able to achieve bank loan after some time. It will happen mostly in underdeveloped countries where financial institutions are not much regularized or countries financial sector is not in a stage to give loans to all loans requiring firms, so in these countries, trade credit usage is quite high (Ge \& Qiu, 2007). In underdeveloped economies like Pakistan and India's firms financed more from the supplier and the economies with well-developed financial markets, Firms financed less by suppliers (Breig, 1996). Trade credit also allows firms to reduce the transaction cost related to the process of paying invoices and the verification of the quality of products before paying. As the customer is more concerned to verify the products before paying for it. Therefore, for low-quality product supplier knew that if the products are not according to the customer demand then the customer may refuse to pay for the product. So, the supplier gives more focus on customer demand to get timely payments (Ferris, 1981).

According to Jaleel, Hui, Virk, \& Abdullah, (2015) firms that focused more on quality products are able to obtain a huge amount of trade credit as compare to the firms 3 which are not very much quality conscious. So, in this scenario trade credit could be seen as a firm's goodwill accelerator. At the same time, it also increases the sale of firms. As many new customers are also attached to firms that are not able to purchase products on a cash basis on the spot. In these way Firms sales increases gradually. Finally, in trade credit, there is an early payment discount term present which makes it cheaper. This means if the customer pays before the due date then the supplier gives it a rebate in price. So, if a customer pays before the due date then the supplier firm gets less amount. Therefore, if there is a long-term relationship between customer and supplier then supplier firms less trade credit due to its rebate cost. As in the case of bank credit, the interest rate cost is fixed so there is no chance that the bank will face any increase in its credit cost, but in trade, credit cost may increase lately due to rebate policy of trade credit supplying firms. In case of trade credit, the payment paid after the contracted date increased the real cost of trade credit, however, the suppliers mostly not charge late payment fees. However, the late payment issue of the trade credit transactions differs across countries to countries and industries to industries. This feature shows an extra degree of flexibility when the issue of repayment arises. Suppliers have the right to act legally against the buyers if the buyer does not repay at the stated maturity. Suppliers often decide to give buyers extra time for repayment. As late payment is concerned it is crucial to understand the long-term relationship between buyer and seller. The supplier has usually been more concerned about the late payment as compared to that of buyers, as the supplier is more focused on the buyer as well as his retention in the business.

Buyers have the ability, to control the quality of the product with the trade credit agreement. As buyers can sell the product in the market and can monitor the quality of the product which is purchased by the customers. This leads to an increase in product demand. The product itself has a security for the seller as if the buyer is unable to sell, the seller himself can sell the product at any time. Therefore, trade credit has the real source of increasing revenue. The supplier provides totally an illiquid input on the other hand bank provides cash which is a totally liquid input. The trade-credit transaction is for all firms despite of their sizes, however it is more efficient for small-sized industries because they are more neglected by financial institutions. According to (Cunat, 2006), if Firms experience the liquidity issues and negative growth rates trade credit also has an effect on the growth process. As per (Petersen \& Rajan, 1997) those Firms which already face financial distress, are more interested to extend trade credit as trade credit is the source for the increase in the sales. This gave flexibility in payment to suppliers. Trade credit extends to many periods of the agreement. Suppliers to accommodate the adjustments in the demand, willingly accept to alter the price of commodities than that of the credit terms. To diversify the risk of the buyer, it has been necessary to distribute the earning of the buyers so that there has been less chance of liquidity faced to the buyer (Smith, 1987) (Beck, Demirgüç-Kunt, \& Maksimovic, 2008). In Pakistan, non-financial firms face scarce financing issues. Hence there is a need for external financing most of the times. As per the study conducted by (Jaleel, Hui, Virk, \& Abdullah, 2015) on the non-financial sector firms of Pakistan. They found that the textile sector is one of the largest sectors of non-financial firms of Pakistan mostly financed by the trade credit. Moreover, the other sectors like chemical sector, sugar industry, motor vehicle, cement etc. are also mostly funded by the trade credit. The conventional bank loans required security which at times becomes difficult for these non-financial firms to provide and so the trade credit becomes an important source of financing in Pakistan for these firms.

\section{Firms which have less trade credits mostly considered as a low-quality production Firms as they offer less time to verify products to customers}




\section{Literature Review}

Firms can fulfill its capital needs using two major financing sources i.e. short-run and long-run financing. Two major sources of long-term financing are issuing shares and debentures and two major sources of short-term financing are bank loan and trade credit. Trade credit is a source of short-term financing which is taking popularity today due to its benefits. As per theory, the issues were due to asymmetric information within the market. There were alternative ways that solve the issues of the short-term financing like trade credit Hence trade credit is an important source of financing for all sizes of firms, but especially small, medium-sized and unstable firms. Because these firms have fewer chances to get a bank loan due to their less market goodwill and low level of assets. Stable firms can easily get help from the financial institutions however unstable firms have to see other resources. There are two ways to use trade credit either for supply or demand for credit goods. As per study for all American firms, trade credit was an important part of the balance sheet in early 1990. Account receivables was recorded as 18 percent as per total assets. As, for example, in United Kingdom, debts of short-term nature have observed to be 70 percent account payable from the balance sheet and 50 percent of debt has recorded as compiled debt of the companies. In France, Germany and Italy trade credit has been observed as one-fourth of all the corporate assets and is important where the firm gets limited support from the banks in emerging economies like China as per Ahmed \& HUI, (2016). A discount offer is an attractive option from the firms' point of view, because, the cost attached to purchase goods or services is reduced. In the case of lending to other firms, the firms have financing advantages to collect and gather the information more quickly and easily compared to that of banks and financial institutions. Suppliers have informational benefits over other financial sectors.

As per Petersen \& Rajan, (1997) suppliers do not discriminate the prices if they work on the price of credit or price of goods, therefore, the supplier may face low profitability. According to Vaidya, (2012) supplier also imposed power on buyers to pay on time otherwise buyer will no longer be served as a customer. As explained by Smith, (1987) the discount given to buyers indicates as a weak financial standing by the seller. According to (Wilson \& Summers, 2002) as a tool, the trade credit has fulfilled all the marketing aspects. In case that a new owner entered into the market, it can gain reputation and success if involved in trade credit transactions instead of spending many years to stand alone trade credit build new business relations. SME's are not able to secure the enough amounts of finances and this caused the SME's to fail quiet more often than other firms (Huyghebaert, Van de Gucht, \& Van Hulle, 2007). According to (Beck et al., 2008) there have numerous studies carried out for the use and existence of the trade credit. According to those studies, buyers and suppliers can avail of the facility of relationships in a case when there has instability in the financial market of the country. According to them trade credit has made up of 70 percent of the debt. The nature of the debt is short term debt. Non-availability of finances always turns the buyers towards new and everlasting sources, especially the trade credit contract serves the purpose. As per smith (1987) trade credit act as a positive signal in the market as compared to banks, which are less liked to lend to the buyers. Smith (1987) stated that trade credit act in a way to finance the company externally also it became cheaper at a discount for early payments. As per Van Horne \& Spence, (1989) trade credit has a direct relation to business and the source of financing for the companies. According to Beck, Demirgüç-Kunt, \& Maksimovic, (2005) trade credit is best for the buyer as well as for the supplier where both the parties mutually share their interests to expand the businesses, in case of inefficient financial markets. SME's can easily get trade credit financing as compared to a bank loan because of the small nature of businesses.

Non-financial firms have their interest in the issue of trade credit because of the fact that knowing complete information about the market these firms have advantages over the other institutions and they efficiently utilize their resources to give maximum output to their companies. In working in the same industry supplier knows very well about the near future aspects of the running companies and has complete knowledge to expand the needs and efforts of the business. Trade credit holds an important role in every corporate financial policy. Funds invested as trade credit financing served the purpose of an investment in the business. (Long, Malitz, \& Ravid, 1993) and (Berger \& Udell, 1995) stated that in European Firms in balance sheet items the total assets of the companies have trade credit supply items. According to (Ge \& Qiu, 2007) trade credit served the purpose of external financing for the countries which are still underdeveloped as these countries have no excess towards the financial institutions and they are unable to meet the policies of financial institutions. From the supplier point of view, in order to discriminate the price to the buyer, supplier extended goods on credit. As per Ferris (1981) as suggested to reduce the transaction cost, trade credit served the best means. (Cunat, 2006) for a deprived customer to maintain a longterm relationship, the supplier's given discount as well as try to settle the liquidity problems of their customers. 
Mostly the use of trade credit has higher in those countries where the production of goods is an integral part of the economy as explained by (Long et al., 1993). Ahmed \& HUI, (2016) examined that the use of trade credit is increased after 2008 due to financial crises in Pakistan. Trade credit is more common among the firms facing bank borrowing constraints as banks required security against the loans. The bank always issues loans to those customers where there has attached a less risk of repayment. Due to an increase in risk the customers are not able to run business, therefore, move towards other short-term trades. Trade credit thus serves as an edge to the buyer to sustain in the competitive market. This showed a strong and effective use of trade credit in developed as well as developing countries (Ahmed \& HUI, 2016). Small companies have more interest to issue trade credit as they have to be more interested to resolve their liquidity issues. According to (Long et al., 1993) Firms get less involved in credit transactions also they don't need to provide the guarantee for their product. As per the study survey Beck et al (2008), 19.7 percent of total financing has been financed through trade credit and is an external source in 48 countries of the world. The author argued that trade credit has the second-largest source of external financing. In developed countries like France and the UK, more than $30 \%$ of finance is external finance as trade credit. In the U.S. $60 \%$ of small businesses used trade credit such a major use of financing than banks and financial institutions as explained by (Elliehausen \& Wolken, 1993). Firms at startup and newly younger Firms rely more on the external source of financing as trade credit.

Ferris, (1981) investigated that the account payable and the trade credit related to total purchases at the purchase time and time of delivery. The high level of risky firms uses more trade credit and pay a higher portion of trade purchase after the due date. Economically significant theories were transaction cost theory and informational asymmetry explained the demand for trade credit. Buyers firms have faced credit-constrained issues as these firms have faced investment opportunities and they can increase their inputs by expanding the business. Also, the increased sales gave an easy to increase their market share and to prosper the business. The commercial banks have more lending channels as compared to those of suppliers to fulfill contract requirements. The main reason for the existence of tax has been to motivate the trade credit because different tax policies for buyers and suppliers showed a way to protect against the highest tax schedule as the case of financial institutions. As the seller has to report the taxable income as per the installment of credit received. In the case of the cash management process, the trade credit serves the purpose to reduce the cost of firm resources.

\section{Methodology}

Data of this study collected from the non-financial firms listed on the Pakistan Stock Exchange (PSX). Selection criteria based on the complete availability of the data set for the years 2001 to 2015. To capture the effect of different independent variables on firm growth the study used the Generalized Method of Moments (GMM).

\subsection{Data}

As per the nature of the trade credit transactions and the difference in capital structure the study has selected nonfinancial firms listed on Pakistan Stock Exchange. Before the year 2001, it is very hard to find and collect the data of all non-financial firms in Pakistan. Because The State Bank of Pakistan did not provide any kind of information regarding the data of financial statements of different businesses. After the year 2001, the SBP started to publish the financial statement data of the non-financial firms. On the other side, the currently available of data set on the website of the State Bank of Pakistan is till the year 2015. So, due to unavailability of data the study has finally collected the data for the years 2001 to 2015. Data are collected from the Balance Sheet Analysis (BSA) and Financial Statement Analysis (FSA) published by the State Bank of Pakistan. Moreover, the missing information about any variable has been confirmed directly from the financial statements of each non-financial firm selected in the sample. To find out the impact of macroeconomic variables in this analysis the study used the two fundamental variables of Gross Domestic Product (GDP) and Inflation rate. The data of these macroeconomic variables are collected from World Development Indicators (WDI) and government monetary policy circulars. According to the Financial Statement Analysis (FSA) 2015 there were 443 non-financial firms listed on a Pakistan Stock Exchange. Non-financial firms which did not provide the complete information even in the financial statements and maybe started their operations recently are excluded from the sample. Non-financial firms which contained some unusual year values are also extracted from the sample. Finally, the data has been collected for 257 non-financial firms of Pakistan.

According to the sample information the greater number of Firms selected in the sample was from the textile sector. As the textile sector has a greater frequency in overall listed non-financial firms listed at Pakistan Stock Exchange. 
It contributes 39.86 percent in the overall sample of selected firms. Chemicals, Chemical Products and Pharma stood at the second number. Thirty-three firms were selected from this sector, it contributes 11.15 percent in the overall sample. (see appendix A, for a complete list of companies of non-financial sector of Pakistan).

\subsection{Variables}

The dependent variable is Firms' Growth which is calculated on the basis of real added value. The calculation of firms' growth on the basis of real added value is presented by Ferrando and mulier in (2013).

In table 3.1 dependent and independent variables are explained with their calculation specifications.

Table 3.1: List of variables

\begin{tabular}{|l|l|l|}
\hline Variable Names & Formula & \multicolumn{2}{l|}{$\begin{array}{l}\text { Reference } \\
\text { FG (Firms Growth) }\end{array}$} & $\begin{array}{l}\text { real added value - lagged real added value } \\
\text { Trade credit (TC) }\end{array}$ & AR, AP & Peterson \& rajan 1997 \\
\hline AR & Account receiveable / Total sales & \\
\hline AP & Account payable / Total purchases & \\
\hline Size & Log of Book Value of Assets & Bougheas et al. 2009 \\
\hline Age & Founded year & (Gertler, 1988) \\
\hline FG (-1) & real added value - lagged real added value & (Ferrando \& Mulier, 2013) \\
\hline GDP & Gross Domestic Product (In billions) & WDI \\
\hline Inf & Inflation Rate & WDI \\
\hline
\end{tabular}

The nature of the data used in this study is of panel data. The Panel data contained the information of multiple cross-sections over time. On the other hand, cross-section and time-series data focus on only one dimension. Time series focuses on time intervals and vary over time and cross-section based on individuals at a specific point in time. The study used the panel data and measure most of its variables as

$$
\mathrm{X}_{\mathrm{it}}, \mathrm{i}=1,2, \ldots \ldots, \mathrm{k}, \mathrm{t}=1,2, \ldots \ldots, \mathrm{n}
$$

Where I represent each cross-section or individually and it is standing for time periods that vary from 1 to $\mathrm{n}$. Data from non-financial Firms were collected over the years. The most suitable type of data set that can be used is panel data. Panel data techniques will be used and discussed in this section. There are two major models normally discussed in the literature of panel data econometrics, fixed and random-effects model. Normally, the error term does not change or vary over time for cross-sections (for example, in case of different countries the climate and geographical boundaries of that country remain constant over time) but adding another term along with the error term make it possible for the error term to vary and remain varied.

According to one of the assumptions of the classical linear regression model the error term should not be correlated with any of the independent variable. If this is so, then a simple the problem of omitted variable biased can arise and the simple, ordinary least squares are no longer useful in this situation. To solve this problem the fixed effect estimation technique or a method of the first difference estimator can be used. On the other hand, if an independent variable is not correlated with the error term, then a simple, ordinary least square method may use to find the consistent and unbiased results. When the error terms correlate with the lagged error term, there arises the problem of autocorrelation. If the same relationship occurs between any other variable and the lag of that specific variable, it can also be known as the serial correlation. To avoid this problem, another efficient estimator is required that might solve this problem. In this case, the random effect model helps to come across the unbiased and efficient estimates. 
Hausman test is used to differentiate the two models. The study has also used the test and found that the fixed effect model is more appropriate.

In most of the case of finance and economics most of the variables depend on their previous behavior or trend. The dependent variable sometimes depends on lag values. If the dependent variable depends on its own lag value this phenomenon is explained as a dynamic panel. The presence of lagged dependent variables is a strong signal of containing the problem of endogeneity and violates the assumption of exogeneity on which the panel data techniques rely. An alternative technique is used to avoid the problem of endogeneity called instrument variable regression. There are three major types of instrumental variable regressions. First, a two-stage least square method that is appropriate where there are simultaneous equations in the model. Secondly, generalizes least square techniques which are based on the assumption when the data is not linear. Third and the last type is the generalized method of moments which is most popular where we have simple linear equations along with lagged dependent variables. In this study, firms are totally different from each other in respect of size, industry type, etc. e.g. cement sector, oil and gas sector, textile sector, etc. So, in every phenomenon they are different from each other in terms of their decisions, growth, business strategy and their sale promotions etc. so data are totally heterogeneous in every respect. To capture this heterogeneity affect the fixed effect model is used. Moreover, since the dependent variable also depends on its previous value. Firms' growth depends on last year's Firms growth means its lagged value so there might be a chance of endogeneity. To capture the endogeneity problem, GMM model is used in this research. (Possibly the first difference).

\subsection{Model Specification}

The general model used is,

$$
\mathbf{Y}_{i t}=\beta_{0}+\sum_{i=1}^{t} \beta_{i} \mathbf{x}_{i t}+\varepsilon_{i t}
$$

Specifically, our model followed by the model presented by (Ferrando \& Mulier, 2013).

Model-1

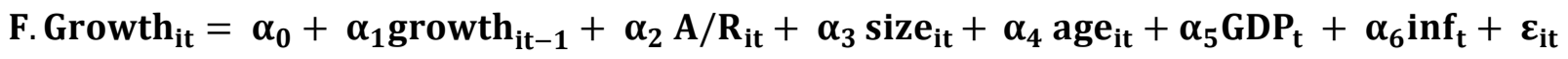

Model-2

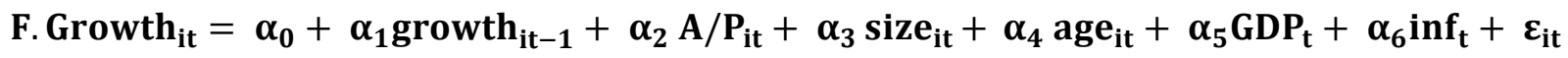

The term (i) stands for industry as in our data the Firms are heterogeneous industry-oriented and (t) is the time period.

The term log of size and the log of age will be used to ensure that any impact of the trade credit channel on growth is not driven by firm size or age. According to (Gertler, 1988) the age is also a constraint in firm growth. They suggested that small size and newly established firms tend to have more difficulties in raising external finance.

\section{Results and Discussion}

4.1 Descriptive Stats

Statistical summary of variables

\begin{tabular}{|l|l|l|l|l|l|l|l|}
\hline & FG & AR2 & AP2 & AGE & SIZE & GDP & INF \\
\hline Mean & 0.90 & 0.24 & 0.30 & 3.38 & 6.82 & 25.77 & 8.76 \\
\hline Median & 0.43 & 0.05 & 0.01 & 3.37 & 6.80 & 25.85 & 8.08 \\
\hline Maximum & 9.89 & 9.90 & 10.00 & 5.04 & 12.20 & 26.32 & 19.60 \\
\hline Minimum & 0.00 & 0.00 & -0.30 & 0.69 & -2.21 & 25.00 & 3.10 \\
\hline Std. Dev. & 1.36 & 0.93 & 1.10 & 0.55 & 1.72 & 0.40 & 4.29 \\
\hline
\end{tabular}


$\mathrm{FG}=$ Firms growth, $\mathrm{INF}=$ Inflation, $\mathrm{AR}=$ Account Receivable, $\mathrm{AP}=$ Account Payable

Source: Authors' computation

\subsection{Correlation Analysis}

Correlation analysis results of dependent and independent variables are shown in table 4.2.

Table 4.2 Relationship among variables

\begin{tabular}{|l|l|l|l|l|l|l|l|}
\hline & FG & INF & GDP & AR & SIZE & AGE & AP \\
\hline FG & 1.000 & & & & & & \\
\hline INF & -0.026 & 1.000 & & & & & \\
\hline & & & & & & & \\
LGDP & 0.015 & 0.403 & 1.000 & & & & \\
AR & 0.002 & -0.152 & 0.165 & 1.000 & & \\
\hline SIZE & -0.012 & 0.068 & 0.228 & -0.082 & 1.000 & & \\
\hline & & & & & & & \\
LAGE & -0.006 & 0.087 & 0.259 & -0.084 & 0.121 & 1.000 & \\
\hline & & & & & & & \\
AP & 0.007 & -0.107 & 0.142 & 0.461 & -0.062 & -0.077 & 1.000 \\
\hline
\end{tabular}

Source: Authors' Computation

\subsection{Data Analysis}

Table 4.3 shows the regression results of our first Model,

Table 4.3: Regression analysis of Model-1

\begin{tabular}{|l|l|l|l|l|}
\hline Variable & Coefficient & Std. Error & t-Statistic & Prob. \\
\hline C & 0.136 & 1.826 & 0.074 & 0.940 \\
\hline FG (-1) & 0.101 & 0.017 & 5.941 & $0.000^{*}$ \\
\hline AR & 0.089 & 0.028 & 3.178 & $0.012^{*}$ \\
\hline INF & -0.078 & 0.016 & -4.875 & $0.014^{*}$ \\
\hline LGDP & 0.079 & 0.036 & 2.191 & $0.036^{*}$ \\
\hline LAGE & -0.100 & 0.067 & -1.492 & 0.126 \\
\hline SIZE & -0.039 & 0.012 & -3.254 & $0.004^{*}$ \\
\hline R-squared & & 0.388 & \\
\hline Adjusted R-squared & & 0.361 & \\
\hline Prob (J-statistic) & & 0.051 & \\
\hline
\end{tabular}

Note: * indicates significant variables.

In this study the dependent variable is firms' growth, the hypothesis was related to the growth of firms which is dependent on many other factors like GDP, Inflation etc. The value of R-square has found 39 percent indicates that 
39 percent of the variation in Firms growth has been explained by these explanatory variables. As the firms' growth depends on the previous lag so, the first independent variable is the lag of firms growth which showed the positive and significant relationship that firms growth depends on its own previous lag. The value of T-statistics is above 2 which indicates that the variable used is significant. P-value is less than 0.05 . AR has a positive significant relationship with firms growth which proves our hypothesis of an increase in AR leads to the increase in firms growth. As sales increased the other sources of growth especially firms' growth is directly influenced. The value of T-statistics is above 2 which indicate that the independent variable AR used is significant to the firms' growth. Pvalue is less than 0.05 so we reject the null hypothesis and accept the alternative hypothesis that AR has a positive impact on firms' growth. Inflation shows a negative significant relationship with that of firms' growth. Hence proved hypothesis regarding inflation has a negative significant impact on firms' growth. The value of T-statistics is above 2 which indicates that inflation used is significant to firms' growth. P-value is less than 0.05 , so we reject the null hypothesis and accept our alternate hypothesis to add reference to this finding. Gross Domestic Product (GDP) gives the positive significant relationship explains that the Gross Domestic Product has been positively related with the firms' growth. If the economy is stable then firms' growth has been achieved and implemented and in case that economy is facing instability then it also affects the firm growth. Hence, it proved the hypothesis regarding GDP and firms' growth. T-statistics is above 2 indicating that GDP used is significant to the dependent variable firms' growth. P-value is below 0.05 so we accept the alternative hypothesis. add a reference to this finding Firms age gives the negative insignificant relationship. Explaining that the firms' growth is not related to the age of the firms. Hence, negative sign shows that the large-scale firms have less growth instead of small firms. As an increase in firms age put the decrease in firms' growth. It proved the hypothesis regarding firms age and Firms growth. T-statistics is below 2 indicating that firms age used is insignificant to the dependent variable firms' growth. P-value is above 0.05 so we accept the null hypothesis. Size gives the negative significant relationship with firms' growth. Firms growth decreases with the increase of the size of firms because large-sized firms are difficult to be managed. Hence, it proved the hypothesis regarding firms' growth and size. T-statistics is above 2 indicating that size used is significant to the dependent variable firms' growth. P-value is below 0.05 so we reject the null hypothesis.

Table 4.4 shows the results of our 2 nd model.

Table 4.4 Regression analysis of Model-2

\begin{tabular}{|l|l|l|l|l|}
\hline Variable & Coefficient & Std. Error & t-Statistic & Prob. \\
\hline C & 0.631 & 2.888 & 0.218 & 0.827 \\
\hline FG (-1) & 0.039 & 0.017 & 2.293 & $0.027^{*}$ \\
\hline AP & 0.081 & 0.036 & 2.253 & $0.004^{*}$ \\
\hline LAGE & -0.280 & 0.292 & -0.959 & 0.337 \\
\hline SIZE & -0.128 & 0.045 & -2.849 & $0.026^{*}$ \\
\hline LGDP & 0.096 & 0.023 & 4.173 & $0.051^{*}$ \\
\hline INF & -0.067 & 0.015 & -4.466 & $0.002^{*}$ \\
\hline R-squared & & 0.367 & \\
\hline Adjusted R-squared & 0.341 & \\
\hline \multicolumn{2}{|l|}{ Prob (J-statistic) } & $0.043^{*}$ & \\
\hline
\end{tabular}

Note: $*$ indicates significant variables.

The value of R-square has found 37 percent indicates that approximately 37 percent of the variation in firms' growth has been explained by these explanatory variables. As the firms' growth depends on the previous lag so, the first independent variable is the lag of firms' growth which shows the significant relationship with firm growth, that firms growth depends on its own previous lag. The value of T-statistics is above 2 which indicates that the variable used is significant. P-value is less than 0.05 so we reject the null hypothesis and accept our alternate hypothesis. Accounts payable has been positive significantly related to the firms' growth which proves the hypothesis that an increase in accounts payable leads to the increase in firms' growth (Schwartz, 1974). The value of T-statistics is above 2 which indicates that the accounts payable is significant to dependent variable firms' growth. P-value is below 0.05 so we reject the null hypothesis and accept the alternative hypothesis. Firms age gives a negative insignificant relationship. Explaining that the firms' growth is not related to the age of the firms. Hence, negative sign shows that the large-scale firms have less growth instead of small firms. As an increase in firms age put the decrease in firms' growth. It proved the hypothesis regarding firms age and firms' growth. T-statistics is below 2 
indicating that firms age used is insignificant to the dependent variable firms' growth. P-value is above 0.05 so we accept the null hypothesis. Size gives the negative significant relationship with firms' growth. Firms growth has not focused on the size of firms because large-sized firms are difficult to be managed. Hence, it proved the hypothesis regarding firms' growth and size of the firm. T-statistics is above 2 indicating that size used is significant to the dependent variable firms' growth. Negative sign shows the negative impact of size on firms' growth, as the size increases the speed of growth decreases. P-value is less than 0.05 so we reject the null hypothesis. Gross Domestic Product (GDP) gives the positive significant relationship explains that the Gross Domestic Product has been positively related with the firms' growth. Hence, it proved the hypothesis regarding GDP and firms' growth. As Tstatistics is above 2 indicating that GDP used is significant to the dependent variable firms' growth. P-value is approximately 0.05 so we accept our alternative hypothesis. Inflation shows a negative significant relationship with that of firms' growth. Hence proved hypothesis regarding inflation has a negative significant impact on firms' growth. As we have stated that the value of T-statistics is above 2 which indicates that inflation used is significant to firms' growth. P-value is below 0.05 so we reject the null hypothesis.

This study findings related to the size of the firms confirm the empirical findings of Wilson \& Summers (2002) that young and small firms use trade credit supply as a means to assure their quality and build their reputation among potential customers in order to increase their market share. In this study, Trade credit results show the clear picture as discuss by Love, Preve, \& Sarria-Allende (2007) they found that industries that are more dependent on trade credit financing grow relatively more rapidly in countries with less developed financial intermediaries. Inflation findings clearly match with the results of Boyd et al. (2001) study which indicates that there is a negative relationship between inflation and financial and non-financial firms sector growth.

\section{Conclusion}

This research tries to capture the effect of trade credit on firms' growth. As previous researchers highlighted the role and importance of trade credit in the arrangement of short-term financing. The prime objective of the study is built on this ground to find out the relationship between trade credit and firms' growth in the case of Pakistani nonfinancial firms. To achieve this objective, the study, use the data of 257 non-financial registered firms of Pakistan. The data consists of 15 years from the year 2001 to 2015. The results of the study proven that approximately all registered non-financial firms of Pakistan use trade credit policies to achieve their firms' growth4. There is a positive and significant relationship between trade credit and firm growth have been captured in the regression analysis. Trade credit plays an important role in the firms' growth. Those firms which have financial constraint and fail to achieve their growth targets can adopt the trade credit policies to achieve their goals. Firms with the best credit policies can find credit supplies and will be in a better position to obtain short term financing. Firms size and age is also affecting the firm growth rate. Regression results shows the negative significant relationship between size and age of firm with firm growth. That means the new firms have a better opportunity of growth instead of the old firms as they have a chance to capture more market share.

\section{References}

Ahmed, J., \& HUI, X.-f. 2016. Investigation of Trade Credit Patterns in Effect with Bank Loan Availability. DEStech Transactions on Social Science, Education and Human Science(seme).

Beck, T., Demirgüç-Kunt, A., \& Maksimovic, V. 2008. Financing patterns around the world: Are small firms different? Journal of Financial Economics, 89(3): 467-487.

Beck, T., Demirgüç-Kunt, A., \& Maksimovic, V. 2005. Financial and legal constraints to growth: does firm size matter? The Journal of Finance, 60(1): 137-177.

Bennouna, K., Meredith, G. G., \& Marchant, T. 2010. Improved capital budgeting decision making: evidence from Canada. Management decision, 48(2): 225-247.

Berger, A. N., \& Udell, G. F. 1995. Relationship lending and lines of credit in small firm finance. Journal of business: $351-381$.

Boyd, J. H., Levine, R., \& Smith, B. D. 2001. The impact of inflation on financial sector performance. Journal of monetary Economics, 47(2): 221-248.

Breig, H. 1996. Financial Regulation and the Banks' Role in European Economies, European Economic Integration as a Challenge to Industry and Government: 325-347: Springer. 
Burns, R., \& Walker, J. 1991. A survey of working capital policy among small manufacturing firms. The Journal of Entrepreneurial Finance, 1(1): 61-74.

Coluzzi, C., Ferrando, A., \& Martinez-Carrascal, C. 2015. Financing obstacles and growth: an analysis for euro area non-financial firms. The European Journal of Finance, 21(10-11): 773-790.

Cunat, V. 2006. Trade credit: suppliers as debt collectors and insurance providers. The Review of Financial Studies, 20(2): 491-527.

Das, S. 1995. Size, age and firm growth in an infant industry: The computer hardware industry in India.

Dunne, P., \& Hughes, A. 1994. Age, size, growth and survival: UK companies in the 1980s. The Journal of Industrial Economics: 115-140.

Dunne, T., Roberts, M. J., \& Samuelson, L. 1989. The growth and failure of US manufacturing plants. The Quarterly Journal of Economics, 104(4): 671-698.

Elliehausen, G., \& Wolken, J. 1993. The Demand for Trade Credit: An Investigation of Motives for Trade Credit use by Small Businesses," Working Paper, The Federal Reserve Board.

Evans, D. S. 1987. The relationship between firm growth, size, and age: Estimates for 100 manufacturing industries. The journal of industrial economics: 567-581.

Ferrando, A., \& Mulier, K. 2013. Do firms use the trade credit channel to manage growth? Journal of Banking \& Finance, 37(8): 3035-3046.

Ferris, J. S. 1981. A transactions theory of trade credit use. The Quarterly Journal of Economics, 96(2): 243-270.

Ge, Y., \& Qiu, J. 2007. Financial development, bank discrimination, and trade credit. Journal of Banking \& Finance, 31(2): 513-530.

Geroski, P., \& Gugler, K. 2004. Corporate growth convergence in Europe. Oxford Economic Papers, 56(4): $597-$ 620.

Gertler, M. 1988. Financial structure and aggregate economic activity: an overview: National Bureau of Economic Research Cambridge, Mass., USA.

Giannetti, M., Burkart, M., \& Ellingsen, T. 2011. What you sell is what you lend? Explaining trade credit contracts. The Review of Financial Studies, 24(4): 1261-1298.

Hall, B. H. 1986. The relationship between firm size and firm growth in the US manufacturing sector: National Bureau of Economic Research Cambridge, Mass., USA.

Harris, M., \& Raviv, A. 1991. The theory of capital structure. the Journal of Finance, 46(1): 297-355.

Huyghebaert, N., Van de Gucht, L., \& Van Hulle, C. 2007. The choice between bank debt and trace credit in business start-ups. Small Business Economics, 29(4): 435-452.

Huynh, K. P., \& Petrunia, R. J. 2010. Age effects, leverage and firm growth. Journal of Economic Dynamics and Control, 34(5): 1003-1013.

Jaleel, A., Hui, X., Virk, M. U., \& Abdullah, M. 2015. Investigation of causal relationship between trade credit and bank loan during the 2008 financial crisis. Journal of Asian Business Strategy, 5(5): 90.

Jovanovic, B. 1982. Selection and the Evolution of Industry. Econometrica: Journal of the Econometric Society: 649-670.

Lee, N. 2014. What holds back high-growth firms? Evidence from UK SMEs. Small Business Economics, 43(1): 183-195.

Long, M. S., Malitz, I. B., \& Ravid, S. A. 1993. Trade credit, quality guarantees, and product marketability. Financial management: 117-127.

Love, I., Preve, L. A., \& Sarria-Allende, V. 2007. Trade credit and bank credit: Evidence from recent financial crises. Journal of Financial Economics, 83(2): 453-469.

March, J. G., \& Shapira, Z. 1987. Managerial perspectives on risk and risk-taking. Management Science, 33(11): 1404-1418.

Marotta, G. 1997. Does trade credit redistribution thwart monetary policy? Evidence from Italy. Applied Economics, 29(12): 1619-1629.

Miwa, Y., \& Ramseyer, J. M. 2008. The implications of trade credit for bank monitoring: Suggestive evidence from 
Japan. Journal of Economics \& Management Strategy, 17(2): 317-343.

Murfin, J., \& Njoroge, K. 2012. Small lending big: The real effects of trade credit demands on constrained suppliers. Available at SSRN.

Ng, C. K., Smith, J. K., \& Smith, R. L. 1999. Evidence on the determinants of credit terms used in interfirm trade. The journal of finance, 54(3): 1109-1129.

Niskanen, J., \& Niskanen, M. 2006. The Determinants of Corporate Trade Credit Policies in a Bank-dominated Financial Environment: the Case of Finnish Small Firms. European Financial Management, 12(1): 81-102.

Oliveira, B., \& Fortunato, A. 2006. Firm growth and liquidity constraints: A dynamic analysis. Small Business Economics, 27(2-3): 139-156.

Petersen, M. A., \& Rajan, R. G. 1997. Trade credit: theories and evidence. The review of financial studies, 10(3): 661-691.

Raheman, A., \& Nasr, M. 2007. Working capital management and profitability-case of Pakistani firms. International review of business research papers, 3(1): 279-300.

Rajan, R. G., \& Zingales, L. 1996. Financial dependence and growth: National bureau of economic research.

Schwartz, R. A. 1974. An economic model of trade credit. Journal of financial and quantitative analysis, 9(4): 643657.

Smith, J. K. 1987. Trade credit and informational asymmetry. The journal of finance, 42(4): 863-872.

Sola, C. M., Teruel, P. J. G., \& Solano, P. M. 2010. Corporate cash holding and firm value. Documentos de Trabajo FUNCAS(503): 1.

Storey, D. J. 2016. Understanding the small business sector: Routledge.

Summers, B., \& Wilson, N. 2002. An empirical investigation of trade credit demand. International Journal of the Economics of Business, 9(2): 257-270.

Vaidya, R. R. 2012. The determinants of trade credit: Evidence from Indian manufacturing firms.

Van Horne, J. C., \& Spence, J. 1989. Fundamentals of financial management: Prentice Hall.

Wilson, N., \& Summers, B. 2002. Trade credit terms offered by small firms: survey evidence and empirical analysis. Journal of Business Finance \& Accounting, 29(3-4): 317-351. 